\title{
Toxic Effects of Four Plant Essential Oils alone and in Combination with Controlled modified Atmosphere on the Cowpea Beetle Callosobruchus maculatus (Fabricius.) (Coleoptera: Bruchidae) under Laboratory Conditions
}

\author{
Elgizawy, K.KH. ${ }^{1}$, Hend, T. Abd El-Halim ${ }^{2}$ and El-Shewy, A.M. ${ }^{1}$ \\ ${ }^{1}$ Plant Protection Department, Faculty of Agriculture, Benha University, Egypt. \\ ${ }^{2}$ Plant Protection Research Institute, Agric. Res. Center, Ministry of Agric., Giza, Egypt. \\ Corresponding author: karam.elgizawy@ fagr.bu.edu.eg
}

\begin{abstract}
Four plant essential oils alone as repellent and fumigant, and in combination with the controlled modified atmospheres against the adult of cowpea weevil, Callosobruchus maculatus Fabricius (Coleoptera: Bruchidae) were assessed in the laboratory. These essential oils were extracted from the leaves of four source plants: Prunus amigdalus, Moringa oleifera, Simmondsia chinensis, and Ricinus communis. The repellency test indicated that $C$. maculatus adults were repelled by four essential oils. Of these essential oils, the P. amigdalus oil was most effective followed by M. oleifera, S. chinensis, and R. communis. The average repellency of the P. amigdalus oil against $C$. maculatus adults was significantly higher than the other three tested oils after 7 days. These essential oils had a high level of toxicity in the fumigation assay against $C$. maculatus adults. The results showed that $P$. amigdalus oil gave the highest toxicity at $\mathrm{LC}_{50}(2.08 \mathrm{ppm})$ and $R$. communis gave the lowest value of $\mathrm{LC}_{50}$ (55.05ppm). In results of the effectiveness of the four essential oils when combined with two controlled atmospheres concentrations, $12.5-25 \% \mathrm{CO}_{2}$, the toxicity of plant oils was enhanced significantly against $C$. maculatus adults. The results of joint toxic action indicated that at concentration $10 \mathrm{ppm}$ of the four essential oils under modified atmospheres of $12.5 \% \mathrm{CO}_{2}$ produced an additive effect at all exposure periods, while in case of M. oleifera and $S$. chinensis gave additive effect at 3 and 5 days exposure periods. The same trend was found at the highest concentration $20 \mathrm{ppm}$ of three essential oils $P$. amigdalus, M. oleifera, and S. chinensis under modified atmospheres of $12.5-25 \% \mathrm{CO}_{2}$ and produced an additive effect at all exposure periods, while Co-toxicity values of $20 \mathrm{ppm} R$. communis essential oil after the various exposer periods showed antagonism effect against $C$. maculatus adults. In conclusion, the present study revealed that the combination of the four tested essential oils with $\mathrm{CO}_{2}$ enhanced its fumigant toxicity to stored product insect, cowpea beetle.
\end{abstract}

Key words: Cowpea beetle, Callosobruchus maculatus, plant essential oil, modified atmosphere, toxicity

\section{Introduction}

In stored products world-wide, insect pest infestation may cause up to $40 \%$ damage Matthews, (1993).Cowpea, Vigna unguiculata (L.) (Walp.), is an important food legume for millions of people throughout the semiarid regions of Africa, Asia, southern Europe, and North, Central, and South America Singh, et al., (2003). The cowpea beetle , Callosobruchus maculatus Fabricius (Coleoptera: Bruchidae), is a cosmopolitan pest of legume seeds and is among the most serious pests of stored products in tropical countries Kang, et al.,(2013), Massango, et al.,(2017). The insect larvae represent the most destructive stage, as adults cowpea bruchid do not feed Ileke, et al., (2017). However, as the availability of a specific host is highly discontinuous and because these adult insects can live in hosts that are normally treated with insecticides Gbaye, et al., (2012).This insect might have to face insecticidal sub-lethal exposures prior to deciding where they are going to lay eggs.

In view of the damage caused by $C$. maculate, fumigants are the most cost-effective and efficient way of managing stored product pests in many storage systems, not just because they are able to kill a wide range of pests, but due to easily penetrate the products and leave minimal residue Mueller, (1990). Phosphine is a common fumigant for these reasons Lee, et al., (2004). Fumigation by phosphine which is widely used may become increasingly districted in use as it makes resistance of stored product insects to this fumigant and some arguments about the genotoxicity potential of phosphine Meaklim, (1998).Safe alternatives to replace dangerous insecticides are therefore urgently required to grow and commercialize. To protect the environment and prevent negative environmental consequences, researchers focused on innovative ways of carrying out insect pest management in grain farms. In addition, they concentrated on using organic products like pesticides, and essential plant oils. Rajendran \& Sriranjini, (2008).

Essential oils are potential alternative material to currently used fumigants Lee et al., (2001). Plant products, including essential and component oils, were used for fumigation because it is thought that plant extracts could benefit from low mammalian toxicity and rapid degradation, as well as local availability, compared with traditional fumigants. Rajendran and Sriranjini, (2008).Some plants with 
medicinal properties contain components have ovicidal, antifeedant, repellent, sterilizing, and toxic effects in insects Isman, (2006)

Controlled atmospheres such as low oxygen levels, high concentrations of carbon dioxide, and reduced pressure are efficient ways of controlling storage insects in particular on the adult stage. Modified atmosphere treatments are safe and environmentally friendly ways to manage pests that cause harm to many stored-products. Over several years, the modified atmosphere has been used to check the control of diverse insect and mite species in the laboratory under industrial conditions. Navarro, (2006).Several stored product insects have been previously investigated for controlled atmosphere mortality Mbata et al., (2009).

In the present work, the efficacy as repellents and fumigants of four plant essential oils alone and in combination with carbon dioxide modified atmospheres have been investigated against the adults of C. maculatus under the laboratory conductions.

\section{Materials and Methods}

\section{- Test Insect and Rearing Conditions.}

The original population of $C$. maculatus was fieldcollected from small farm stores in Moshtohor region (Qaliubiya Governorate, Egypt) during the year 2020, and the population was placed (25 pairs of 2-day-old male and female beetles) in $1 \mathrm{~L}$ wide-mouthed glass Mason jars containing $100 \mathrm{~g}$ of cowpea seeds maintained free from pest and insecticides. The jars were placed in a rearing chamber and maintained at $28 \pm 2{ }^{\circ} \mathrm{C}, 70 \pm 5 \%$ R.H, and $12: 12 \mathrm{~h}$ photoperiod. Female beetles were allowed to lay eggs on the seeds for 24 hours, after which they were removed. The seeds containing eggs were kept in a rearing chamber until adult emergence. Tests were performed in the stored product pests Laboratory at the Plant Protection Department, Faculty of Agriculture, Moshtohor, Benha University.

\section{- Plant Essential Oils.}

Four plant species belonging to four different families; Rosaceae, Moringaceae, Simmondsiaceae and Euphorbiaceae; were used during these investigations. Theses essential oils were bought from Al-gomhuria Company of drugs, chemicals and medical supplies in Egypt. The fumigant toxicity of this oils were tested to the adults of $C$. maculatus. The source plants for oil extraction were: Prunus amigdalus, Moringa oleifera, Simmondsia chinensis and Ricinus communis (Table 1).

Table 1. The plant species were as follows:

\begin{tabular}{llll}
\hline \multicolumn{1}{c}{ Scientific name } & English name & $\begin{array}{c}\text { Arabic } \\
\text { name }\end{array}$ & \multicolumn{1}{c}{ Family } \\
\hline Prunus amigdalus & Bitter almond & Rosaceae \\
Moringa oleifera & Moringa & اللورينجا & Moringaceae \\
Simmondsia chinensis & Jojoba & Simmondsiace \\
Ricinus communis & Castor & ae & Euphorbiaceae \\
\hline
\end{tabular}

\section{- Bioassay}

\section{a- Repellency test}

Repellency of four essential oils against $C$. maculatus was carried out using an apparatus described by $\mathrm{Su},(1989)$ with some modifications. A metallic ring $(6 \mathrm{~cm}$ diameter $\times 0.5 \mathrm{~cm}$ height $)$ was placed in the center of a glass Petri-dish $(11 \mathrm{~cm}$ diameter $\mathrm{x} 3 \mathrm{~cm}$ height) on a filter paper. The filter paper was dipped in solutions of the test materials in acetone to achieve deposits at 200, 400, or 800 $\mu \mathrm{g} / \mathrm{cm}^{2}$. Ten grams of the treated samples were placed inside the ring. Thirty adults (1-2 week old) were introduced to the sample after two days from initial treatment. Treatment samples were kept for $24 \mathrm{hrs}$ then repellency rate was recorded based on the number of insects counted inside and outside the ring after 1, 2, 3, 5, and 7 days from the initial treatment, Thirty newly adults were introduced to the same sample, then repellency was recorded at each period after $24 \mathrm{hr}$.

\section{b- Fumigant Toxicity Test}

In this experiment $200 \mathrm{ml}$ glass jars with tilted covers were used as fumigation chambers for the plant oil. The tested concentrations of each oil inside the jars were $2.5,5,10,20$ and $40 \mathrm{ppm}$. Total six jars (replicates) were set up in each glass bottle. Inside every jar one filter paper was inserted at the button. Then one $\mathrm{ml}$ from each oil concentration (in acetone) was taken and added to every glass jar on a filter paper. Thirty adults were put inside each jar into wire gauze cages ( $40 \mathrm{~mm}$ in diameter and $45 \mathrm{~mm}$ in height) with a small amount of diet. The jars were well closed and incubated at $28 \pm 1{ }^{\circ} \mathrm{C}$ and $65 \pm 5 \%$ R.H. The same steps were followed in the control treatment using only acetone without oil. Mortality rate was calculated after 1, 2, 3, 5 and 7 days post treatment. Each treatment with the respective control was replicated six times.

\section{c- Effect of modified atmosphere}

Carbon dioxide was provided as pure gases in pressure steel cylinders. Each cylinder was connected with a pressure regulator. The dilution method was used to achieve the required $\mathrm{CO}_{2}$ concentration. Modified atmospheres of 12.5, 25and 50\% $\mathrm{CO}_{2}$ were prepared and tested. Carbon dioxide was monitored using Gas analyzer model 200-600 (Gow-MacInstrument Co., USA). Batches of Thirty adults were introduced into wire gauze cages $(40 \mathrm{~mm}$ in diameter and $45 \mathrm{~mm}$ in height), filled with about $10 \mathrm{~g}$ diet (Cowpea seeds)then the cages were covered with rubber stopper. Cages were taken and introduced it into Dreshel-flask of $0.55 \mathrm{~L}$.Insects in the gas tight flasks were treated for different fixed exposure periods at the aforementioned temperature and relative humidity. The flasks were aireated and the insects were transferred into petri dishes and kept it at $25^{\circ} \pm 1^{\circ} \mathrm{C}$ and $60 \pm 5 \% \mathrm{RH}$ for mortality assessment. 
The controlled atmosphere apparatus used in this experiment was described by Darwish, et al., (1993) with some modifications.

\section{d- Combination Toxicity Test}

Ten grams of Cowpea seeds were treated with four essential oils at two concentrations 10 and $20 \mathrm{ppm}$ as described above. Thirty insects were introduced into each cage. Insects inside the cages were transferred into the Dreshei-flask, and exposed to two concentrations of carbon dioxide. Tests were conducted at the same temperature and relative humidity at different exposure periods and insect mortalities were assessed as described above. The essential oils and controlled atmosphere combinations used in this experiment were described by El-lakwah, et al., (2000) with some modifications.

\section{e- Calculation of joint action}

For the evaluation of the joint action of four plant essential oils with the modified atmospheres, the following equation was adopted as reported by Mansour et al., (1996):

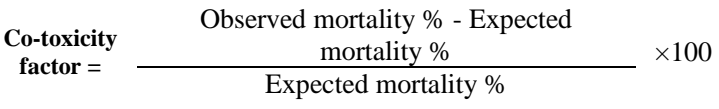

This factor was used to classify the results into three categories. A positive factor of 20 or more means potentiation (synergistic effect), a negative factor of 20 or more means antagonism, and any intermediate value, i.e. between +20 and -20 was considered as additive effect.

\section{- Statistical analysis:}

The data were corrected using data from treatments and the control according to Abbott's formula Abbott, (1925) and the data were subjected to probit analyses using LDP line software according to Finney, (1971)to estimate $\mathrm{LC}_{50}, \mathrm{LC}_{95}$ andLT $\mathrm{L}_{50}$, $\mathrm{LT}_{95}$ values of the essential oils against each stored product insect species. Mortality percentages for different exposure times were subjected to analysis of variance (one-way ANOVA) using the same statistical program (SPSS 2001) for probit analysis Steel et al., (1997).Means were separated at the 5\% significance level by the least significant difference (LSD) test.

\section{Results}

\section{a- Repellency Test.}

Data on repellency of four plant essential oils with three concentrations against $C$. maculatus adults are presented in Table (2) and Fig.(1). Repellency studies conducted after 1, 2, 3, 5, and 7 days of treatment, the results showed that the repellency increased with increasing concentration and reduced with increasing the period of exposure.

Table 2. Corrected repellency percentage (\%) of four plant essential oils against $C$. maculatus adults at different time periods after treatment.

\begin{tabular}{cccccccc}
\hline & & \multicolumn{3}{c}{ Exposure period (days) } \\
\cline { 3 - 7 } Source plants & $\begin{array}{c}\text { Rate } \\
\left(\mu \mathrm{g} / \mathrm{cm}^{2}\right)\end{array}$ & $1 \mathrm{~d}$ & $2 \mathrm{~d}$ & $3 \mathrm{~d}$ & $5 \mathrm{~d}$ & $7 \mathrm{~d}$ & $\begin{array}{c}\text { The average } \\
\text { repellency } \\
\%\end{array}$ \\
\hline \multirow{3}{*}{ P. amigdalus } & 800 & 94.4 & 92.2 & 85.5 & 73.3 & 65.5 & 82.18 \\
& 400 & 85.5 & 81.1 & 76.6 & 68.8 & 53.3 & 73.06 \\
& 200 & 68.8 & 60 & 54.4 & 43.3 & 40 & 53.30 \\
M. oleifera & 800 & 84.4 & 75.5 & 61.1 & 50 & 42.2 & 62.64 \\
& 400 & 78.8 & 61.1 & 52.2 & 33.3 & 25.5 & 50.18 \\
S. chinensis & 200 & 52.2 & 31.1 & 22.2 & 13.3 & 13.3 & 26.42 \\
& 800 & 64.4 & 58.8 & 42.2 & 25.5 & 21.1 & 42.40 \\
R. communis & 400 & 43.3 & 38.8 & 32.2 & 20 & 18.8 & 30.62 \\
& 200 & 38.8 & 25.5 & 18.8 & 12.2 & 0 & 19.06 \\
& 800 & 48.8 & 31.1 & 22.2 & 13.3 & 6.6 & 24.4 \\
& 400 & 22.2 & 15.5 & 8.8 & 5.5 & 0 & 10.40 \\
\end{tabular}




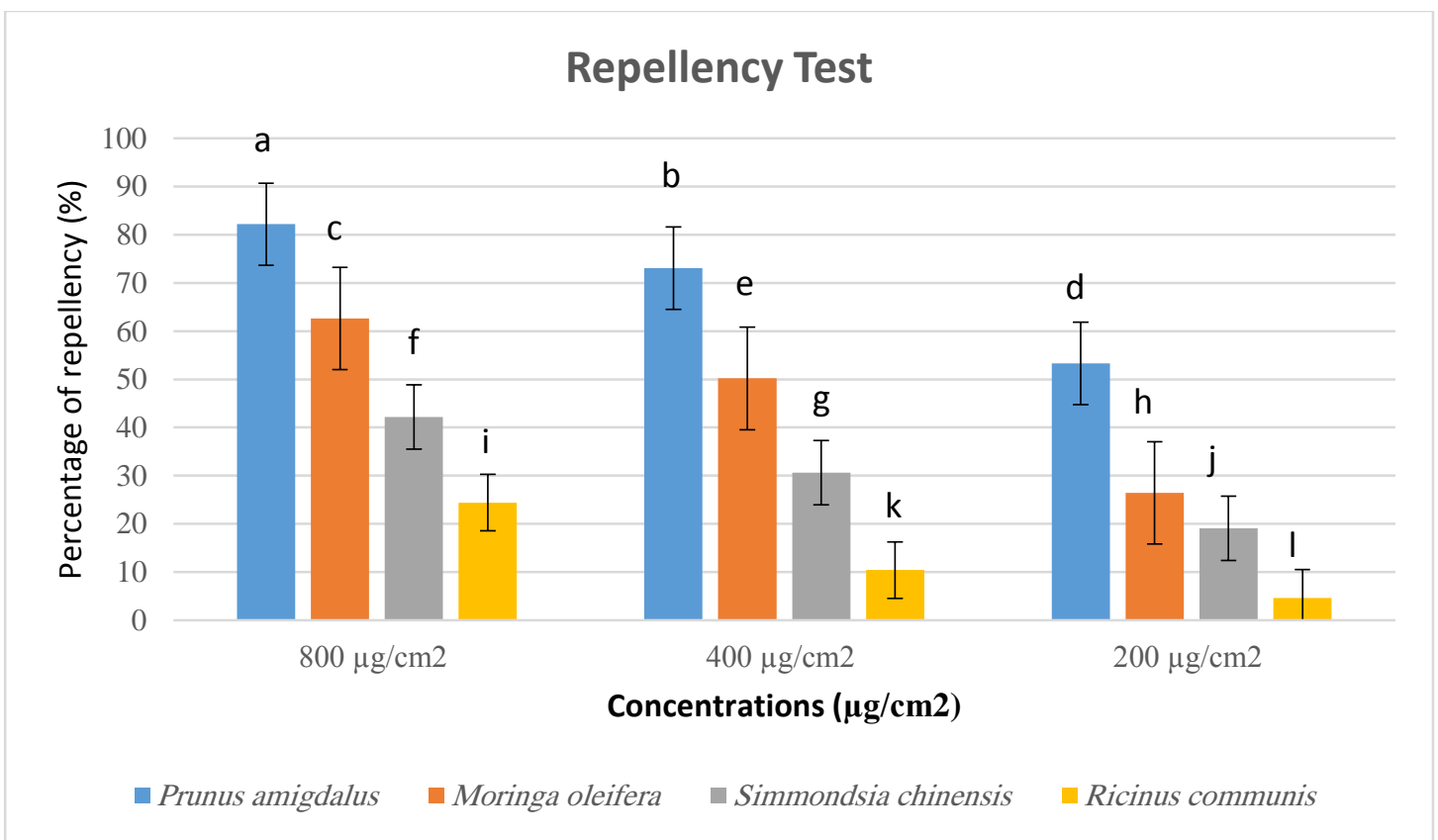

Fig. 1. Average percentage of repellency (mean \pm SD) of four plant essential oils at 200, 400 and $800 \mu \mathrm{g} / \mathrm{cm}^{2}$ against $C$. maculatus adults after day 7 . Means with the same litters are not significantly different. Different superscripts denote $\mathrm{p} \leq .05$ between treatments.

However, the repellency of the tested oils against $C$. maculatus adults at different times were significantly different. More than $50 \%$ of $C$. maculatus adults were repelled after 7 days for the $P$. amigdalus essential oil at 200,400 , and $800 \mu \mathrm{g} / \mathrm{cm}^{2}$, and of M. oleifera at 400 , and $800 \mu \mathrm{g} / \mathrm{cm}^{2}$. The $S$. chinensis oil obtained $42.4 \%$ of repellency after 7 days but at the higher concentration $\left(800 \mu \mathrm{g} / \mathrm{cm}^{2}\right)$. R. communis essential oil was the lowest repellent activity against $C$. maculatus adults at the various concentrations after the exposure periods. Within 7 days, the average percentage of repellency of the four essential oils at three test concentrations against $C$. maculatus adults were significantly different. Of all these essential oils, the $P$. amigdalus oil was the most effective followed by $M$. oleifera and $S$. chinensis. The average repellency of $R$. communis oil against $C$. maculatus adults was significantly lower than the other three tested oils within 7 days.

\section{b- Essential oils Fumigant Toxicity Test.}

The results of the four essential oil fumigation toxicity alone at five concentrations $(40,20,10,5$, and $2.5 \mathrm{ppm}$ ) on the adult of $C$. maculatus at $28 \pm 1^{\circ} \mathrm{C}$ and $65 \pm 5 \%$ R.H. are presented in Table (3). The results showed that mortality was increased by increasing the plant essential oil concentration and period of exposure. At the highest concentration $40 \mathrm{ppm}$ the mortalities were $35.5,23.3,15.5$, and $12.2 \%$ after 1 day exposure and increased after 7 days posttreatment to $83.3,68.8,54.4$ and $48.8 \%$ for $P$. amigdalus, $M$. oleifera, $S$. chinensis, and $R$. communis respectively., while at the lowest concentration $2.5 \mathrm{ppm}$ the mortalities were $18.8,12.2$, 3.3 and zero $\%$ after 1-day exposure and increased after 7 days to $54.4,38.8,20$ and $15.5 \%$ for the same essential oils, respectively. The lethal concentrations of four plant essential oils against $C$. maculatus adults are shown in Table (4). The results showed that the lethal concentrations are exposure period dependent. The higher the exposure period was the lower the LC values. After3 days post-treatment the $\mathrm{LC}_{50}$ values were $18.80,73.51,125.67$, and $169.64 \mathrm{ppm}$ and declined to 2.08, 7.45, 27.81, and $55.05 \mathrm{ppm}$ at 7 days post-treatment for $P$. amigdalus, $M$. oleifera, $S$. chinensis, and $R$. communis respectively, the $\mathrm{LC}_{95}$ values were $1125.91,71549.55,16709.60$, and 11438 ppm, the corresponding values at 7 days were significantly lower and amounted 723.35, 1894.15, 2269.44, and 5447.22 ppm for the same essential oils, respectively. The results indicated clearly that $P$. amigdalus was the highest essential oil toxicity against $C$. maculatus adults followed by $M$. oleifera and $S$. chinensis, while $R$. communis was the least essential oil activity against the target insects. 
Table. 3. Corrected percent mortality of the fumigation toxicity of four essential oils against the adults of $C$. maculatus after exposure period

\begin{tabular}{|c|c|c|c|c|c|}
\hline \multirow{2}{*}{$\begin{array}{l}\text { Concentration } \\
\text { PPM }\end{array}$} & \multicolumn{5}{|c|}{ Accumulative adult mortality (\%) after indicated days } \\
\hline & 1 & 2 & 3 & 5 & 7 \\
\hline \multicolumn{6}{|c|}{ Prunus amigdalus } \\
\hline 40 & 35.5 & 48.8 & 65.5 & 78.8 & 83.3 \\
\hline 20 & 28.8 & 34.4 & 45.5 & 53.3 & 71.1 \\
\hline 10 & 21.1 & 31.1 & 38.8 & 47.7 & 63.3 \\
\hline 5 & 18.8 & 24.4 & 33.3 & 45.5 & 60 \\
\hline 2.5 & 18.8 & 20 & 26.6 & 38.8 & 54.4 \\
\hline \multicolumn{6}{|c|}{ Moringa oleifera } \\
\hline 40 & 23.3 & 37.7 & 44.4 & 56.6 & 68.8 \\
\hline 20 & 20 & 28.8 & 36.6 & 42.2 & 62.2 \\
\hline 10 & 15.5 & 25.5 & 33.3 & 40 & 54.4 \\
\hline 5 & 12.2 & 21.1 & 27.7 & 34.4 & 42.2 \\
\hline 2.5 & 12.2 & 18.8 & 22.2 & 31.1 & 38.8 \\
\hline \multicolumn{6}{|c|}{ Simmondsia chinensis } \\
\hline 40 & 15.5 & 25.5 & 34.4 & 41.1 & 54.4 \\
\hline 20 & 12.2 & 18.8 & 28.8 & 35.5 & 48.8 \\
\hline 10 & 8.8 & 12.2 & 18.8 & 24.4 & 32.2 \\
\hline 5 & 5.5 & 10 & 14.4 & 20 & 24.4 \\
\hline 2.5 & 3.3 & 3.3 & 8.8 & 14.4 & 20 \\
\hline \multicolumn{6}{|c|}{ Ricinus communis } \\
\hline 40 & 12.2 & 21.1 & 28.8 & 36.6 & 48.8 \\
\hline 20 & 12.2 & 15.5 & 18.8 & 28.8 & 33.3 \\
\hline 10 & 5.5 & 10 & 14.4 & 18.8 & 27.7 \\
\hline 5 & 1.1 & 4.4 & 8.8 & 12.2 & 18.8 \\
\hline 2.5 & 0 & 1.1 & 4.4 & 10 & 15.5 \\
\hline
\end{tabular}

Table 4. $\mathrm{LC}_{50}$ and $\mathrm{LC}_{95}$ values of the fumigation toxicity of four essential oils against the adults of $C$. maculatus.

\begin{tabular}{|c|c|c|c|c|c|c|c|}
\hline Plant oils & $\begin{array}{l}\text { Time } \\
\text { (days) }\end{array}$ & $\begin{array}{c}\mathrm{LC}_{50} \\
(\mathrm{ppm})\end{array}$ & $\begin{array}{l}\mathrm{LC}_{95} \\
(\mathrm{ppm})\end{array}$ & Slop \pm SD & $\begin{array}{c}\text { Chi } \\
\text { Square } \\
\left(\chi^{2}\right)\end{array}$ & p-Value & $\mathrm{R}$. \\
\hline \multirow{2}{*}{ P. amigdalus } & $3 d$ & $\begin{array}{c}18.80 \\
13.79-28.94\end{array}$ & $\begin{array}{c}1125.91 \\
360.77-9606.60\end{array}$ & $0.92 \pm 0.14$ & 2.22 & 0.52 & 0.975 \\
\hline & $7 \mathrm{~d}$ & $\begin{array}{c}2.08 \\
0.55-3.75\end{array}$ & $\begin{array}{c}723.35 \\
179.26-25620.37\end{array}$ & $0.64 \pm 0.14$ & 1.83 & 0.60 & 0.956 \\
\hline \multirow[t]{2}{*}{ M. oleifera } & $3 d$ & $\begin{array}{c}73.51 \\
33.60-690.73\end{array}$ & $\begin{array}{c}71549.55 \\
3366.88- \\
1238628321.1\end{array}$ & $0.55 \pm 0.14$ & 0.21 & 0.97 & 0.992 \\
\hline & $7 \mathrm{~d}$ & $\begin{array}{c}7.45 \\
4.47-11.11\end{array}$ & $\begin{array}{c}1894.15 \\
396.65-74849.81\end{array}$ & $0.68 \pm 0.14$ & 0.49 & 0.92 & 0.989 \\
\hline \multirow{2}{*}{ S. chinensis } & $3 d$ & $\begin{array}{c}125.67 \\
58.67-712.57\end{array}$ & $\begin{array}{c}16709.60 \\
1950.13-2933582\end{array}$ & $0.77 \pm 0.16$ & 0.35 & 0.94 & 0.993 \\
\hline & $7 \mathrm{~d}$ & $\begin{array}{c}27.81 \\
19.11-51.47\end{array}$ & $\begin{array}{c}2269.44 \\
572.19-35902.69\end{array}$ & $0.86 \pm 0.15$ & 1.16 & 0.76 & 0.983 \\
\hline \multirow[t]{2}{*}{ R. communis } & $3 \mathrm{~d}$ & $\begin{array}{c}169.64 \\
76.70- \\
1001.52\end{array}$ & $\begin{array}{c}11438 \\
1607.34-1113686.4\end{array}$ & $0.89 \pm 0.18$ & 0.24 & 0.96 & 0.994 \\
\hline & $7 \mathrm{~d}$ & $\begin{array}{c}55.05 \\
32.75-150.81\end{array}$ & $\begin{array}{c}5447.22 \\
1012.29-202275.93\end{array}$ & $0.82 \pm 0.15$ & 1.36 & 0.71 & 0.977 \\
\hline
\end{tabular}




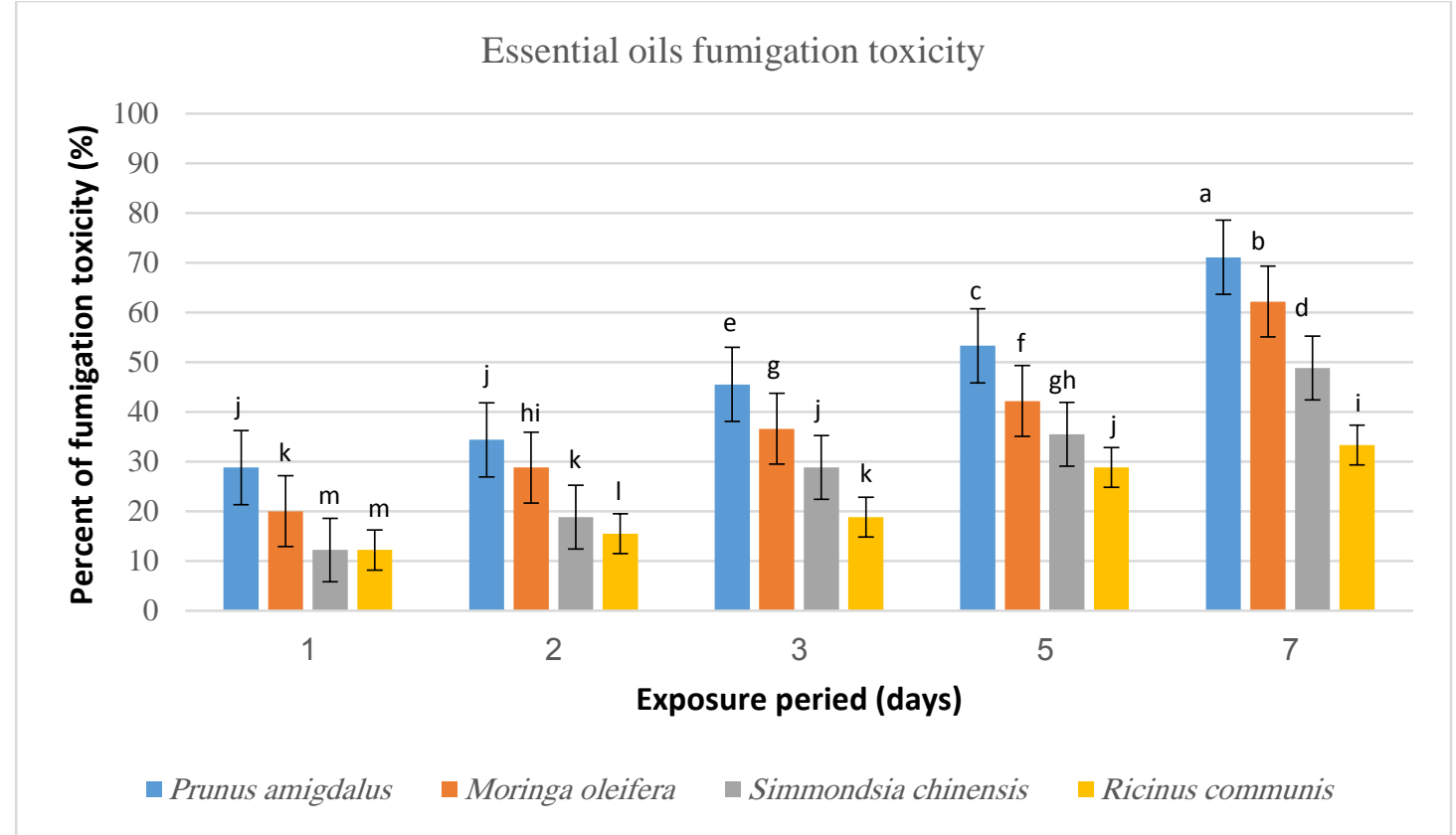

Fig. 2. Average percentage of fumigation toxicity (mean \pm SD) of four plant essential oils at 20ppm against $C$. maculatus adults after exposure period. Means with the same litters are not significantly different. Different superscripts denote $\mathrm{p} \leq .05$ between treatments.

c- Modified atmospheres toxicity Test.

The efficacy of modified atmospheres (MA) containing various carbon dioxide $\left(\mathrm{CO}_{2}\right)$ concentrations against the adults of $C$. maculatus at 28 $\pm 1^{\circ} \mathrm{C}$ and $65 \pm 5 \%$ R.H. are shown in Table (5). It is obvious that using MA at concentrations 12.5, 25, and $50 \% \mathrm{CO}_{2}$ after a 2-days exposure period resulted in $8.8,10.0$, and $32.2 \%$, the mortalities were increased after 7 days exposure period to 35.5, 65.5 and 92.2\% mortality for the cowpea beetle, C. maculatus, respectively. Elevation of mortalities was concentrations and exposure period dependent, since using the MA of $50 \% \mathrm{CO}_{2}$ produced higher mortality values. The results revealed that in Table (6), the time needed to obtain $50 \%$ mortality at $12.5,25$, and $50 \%$ $\mathrm{CO}_{2}$ were $10.92,4.84$, and 2.46 days for the cowpea beetle, $C$. maculatus, respectively. The results showed that high concentration gave mortality values more than low concentration which mean that mortality increased by increasing the $\mathrm{CO}_{2}$ concentration.

Table 5. Efficacy of modified atmospheres (MA) containing various carbon dioxide $\left(\mathrm{CO}_{2}\right)$ concentrations against the adults of $C$. maculatus

\begin{tabular}{cccccc}
\hline Modified atmospheres & \multicolumn{5}{c}{ Accumulative adult mortality (\%) after indicated days } \\
\cline { 2 - 6 } concentration (\%) & 1 & 2 & 3 & 5 & 7 \\
$50 \% \mathrm{CO}_{2}+40 \% \mathrm{~N}_{2}+10 \%$ & 12.2 & 32.2 & 65.5 & 88.8 & 92.2 \\
$\mathrm{O}_{2}$ & & & & & \\
$25 \% \mathrm{CO}_{2}+60 \% \mathrm{~N}_{2}+15 \%$ & 2.2 & 10.0 & 37.7 & 48.8 & 65.5 \\
$\mathrm{O}_{2}$ & 1.1 & 8.8 & 18.8 & 25.5 & 35.5 \\
\hline $\begin{array}{c}12.5 \% \mathrm{CO}_{2}+70 \% \mathrm{~N}_{2}+17.5 \% \\
\mathrm{O}_{2}\end{array}$ &
\end{tabular}

Table 6. $\mathrm{LT}_{50}$ and $\mathrm{LT}_{95}$ values of the fumigation toxicity of modified atmospheres (MA) containing various carbon dioxide $\left(\mathrm{CO}_{2}\right)$ concentrations against the adults of $C$. maculatus.

\begin{tabular}{|c|c|c|c|c|c|c|}
\hline $\begin{array}{l}\text { Modified atmospheres } \\
\text { concentration }(\%)\end{array}$ & $\begin{array}{c}\mathrm{LT}_{50} \\
\text { (days) }\end{array}$ & $\begin{array}{c}\mathrm{LT}_{95} \\
\text { (days) }\end{array}$ & Slop \pm SD & $\begin{array}{l}\text { Chi Square } \\
\left(\chi^{2}\right)\end{array}$ & $\mathrm{p}$-Value & R. \\
\hline $50 \% \mathrm{CO}_{2}+40 \% \mathrm{~N}_{2}+10 \% \mathrm{O}_{2}$ & $\begin{array}{c}2.46 \\
1.70-3.32\end{array}$ & $\begin{array}{c}8.48 \\
7.08-20.65\end{array}$ & $3.06 \pm 0.27$ & 8.97 & 0.02 & 0.991 \\
\hline $25 \% \mathrm{CO}_{2}+60 \% \mathrm{~N}_{2}+15 \% \mathrm{O}_{2}$ & $\begin{array}{c}4.84 \\
4.31-5.55\end{array}$ & $\begin{array}{c}18.79 \\
14.09-28.62\end{array}$ & $2.79 \pm 0.28$ & 5.97 & 0.11 & 0.984 \\
\hline $12.5 \% \mathrm{CO}_{2}+70 \% \mathrm{~N}_{2}+17.5 \% \mathrm{O}_{2}$ & $\begin{array}{c}10.92 \\
8.10-18.51 \\
\end{array}$ & $\begin{array}{c}89.21 \\
41.40-379.84 \\
\end{array}$ & $1.80 \pm 0.28$ & 1.09 & 0.77 & 0.990 \\
\hline
\end{tabular}




\section{d- Essential oil-carbon dioxide combination toxicity \\ The toxicities of four essential oils at two} concentrations 10 and $20 \mathrm{ppm}$ in combination with two modified controlled atmospheres against $C$. maculatus adults are presented in Table (7). The data clearly showed that the tested insect was more sensitivity to the essential oils when applied under MA comparing with the essential oils alone. Complete moralities were recorded after 7-days exposure period when three essential oils $P$. amigdalus, $M$. oleifera, and $S$. Chinensis were used at the highest concentration under MA of $25 \% \mathrm{CO}_{2}$, while the percentage mortality was $82.2 \%$ at the highest concentration of $R$. communist essential oil against the adult of $C$. maculatus. The lethal time values to obtain $50 \%$ mortality of four essential oils in combination with two modified controlled atmospheres against $C$. maculatus adults are presented in Table (8). The lethal time values at the lowest concentration $10 \mathrm{ppm}$ of four essential oils under MA of $25 \% \mathrm{CO}_{2}$ were 1.82, 2.27, 3.45 and 6.20 days, while that the times needed to achieve $95 \%$ mortality were $10.37,11.57,21.48$ and 104.45 days for same treatment, respectively. The lethal time values at the highest concentration $20 \mathrm{ppm}$ of four essential oils under MA of $25 \% \mathrm{CO}_{2}$ were 0.99 , $1.25,1.56$ and 2.66days, while that the times needed to achieve $95 \%$ mortality were $3.91,5.81,8.32$ and 17.21 days for same treatment, respectively.

The calculated joint action of four essential oils at $10 \& 20 \mathrm{ppm}$ in combination with two modified controlled atmosphere against $C$. maculatus adults are given in Tables (9\&10). Results indicated that at concentration $10 \mathrm{ppm}$ of four essential oils under MA of $12.5 \% \mathrm{CO}_{2}$ produce additive effect at all exposure periods, while in case of $M$. oleifera and $S$. chinensis at the same concentrations produced additive effect at 3 and 5 days exposure period. On the other hand, Cotoxicity values of $10 \mathrm{ppm}$ of four essential oils under MA of $25 \% \mathrm{CO}_{2}$ showed additive effects with all the exposure periods. Also at the highest concentration 20 ppm of three essential oils $P$. amigdalus, $M$. oleifera and $S$. chinensis under MA of $12.5 \%$ as well as $25 \%$ $\mathrm{CO}_{2}$ produced additive effect at all exposure periods, while Co-toxicity values of $20 \mathrm{ppm} R$. communis essential oils after the various exposer periods showed antagonism effect against $C$. maculatus adults

Table 7. Corrected percent mortality of the four plant essential oils fumigation toxicity and in combination with two modified atmospheres treatments against the adults of $C$. maculatus after exposure periods

\begin{tabular}{|c|c|c|c|c|c|}
\hline \multirow{2}{*}{ Concentration } & \multicolumn{5}{|c|}{ Accumulative adult mortality (\%) after indicated days } \\
\hline & 1 & 2 & 3 & 5 & 7 \\
\hline \multicolumn{6}{|c|}{ Prunus amigdalus } \\
\hline $10 \mathrm{ppm}+12.5 \mathrm{CO}_{2}$ & 28.8 & 35.5 & 53.3 & 73.3 & 84.4 \\
\hline $10 \mathrm{ppm}+25 \mathrm{CO}_{2}$ & 32.2 & 48.8 & 66.6 & 81.1 & 95.5 \\
\hline $20 \mathrm{ppm}+12.5 \mathrm{CO}_{2}$ & 34.4 & 55.5 & 76.6 & 88.8 & 100 \\
\hline $20 \mathrm{ppm}+25 \mathrm{CO}_{2}$ & 53.3 & 74.4 & 91.1 & 100 & 100 \\
\hline \multicolumn{6}{|c|}{ Moringa oleifera } \\
\hline $10 \mathrm{ppm}+12.5 \mathrm{CO}_{2}$ & 21.1 & 30 & 52.2 & 65.5 & 82.2 \\
\hline $10 \mathrm{ppm}+25 \mathrm{CO}_{2}$ & 25.5 & 33.3 & 64.4 & 78.8 & 88.8 \\
\hline $20 \mathrm{ppm}+12.5 \mathrm{CO}_{2}$ & 41.1 & 58.8 & 74.4 & 85.5 & 94.4 \\
\hline $20 \mathrm{ppm}+25 \mathrm{CO}_{2}$ & 44.4 & 63.3 & 81.1 & 93.3 & 100 \\
\hline \multicolumn{6}{|c|}{ Simmondsia chinensis } \\
\hline $10 \mathrm{ppm}+12.5 \mathrm{CO}_{2}$ & 14.4 & 18.8 & 33.3 & 52.2 & 64.4 \\
\hline $10 \mathrm{ppm}+25 \mathrm{CO}_{2}$ & 16.6 & 22.2 & 48.8 & 63.3 & 74.4 \\
\hline $20 \mathrm{ppm}+12.5 \mathrm{CO}_{2}$ & 23.3 & 44.4 & 62.2 & 75.5 & 88.8 \\
\hline $20 \mathrm{ppm}+25 \mathrm{CO}_{2}$ & 38.8 & 51.1 & 68.8 & 84.4 & 100 \\
\hline \multicolumn{6}{|c|}{ Ricinus communis } \\
\hline $10 \mathrm{ppm}+12.5 \mathrm{CO}_{2}$ & 10 & 15.5 & 24.4 & 33.3 & 45.5 \\
\hline $10 \mathrm{ppm}+25 \mathrm{CO}_{2}$ & 14.4 & 23.3 & 38.8 & 44.4 & 55.5 \\
\hline $20 \mathrm{ppm}+12.5 \mathrm{CO}_{2}$ & 16.6 & 28.8 & 46.6 & 53.3 & 67.7 \\
\hline $20 \mathrm{ppm}+25 \mathrm{CO}_{2}$ & 18.8 & 37.7 & 58.8 & 71.1 & 82.2 \\
\hline
\end{tabular}


Table 8. $\mathrm{LT}_{50}$ and $\mathrm{LT}_{95}$ values of the four plant essential oils fumigation toxicity and in combination with two modified atmospheres treatments against the adults of $C$. maculatus

\begin{tabular}{|c|c|c|c|c|c|c|c|}
\hline Plant oils & Concentrations & $\begin{array}{c}\mathrm{LT}_{50} \\
\text { (days) } \\
\end{array}$ & $\begin{array}{l}\mathrm{LT}_{95} \\
\text { (days) }\end{array}$ & Slop \pm SD & $\begin{array}{c}\text { Chi Square } \\
\left(\chi^{2}\right)\end{array}$ & p-Value & $\mathrm{R}$. \\
\hline \multirow{4}{*}{ P. amigdalus } & $\begin{array}{l}10 \mathrm{ppm}+12.5 \\
\mathrm{CO}_{2}\end{array}$ & $\begin{array}{c}2.40 \\
2.02-2.79\end{array}$ & $\begin{array}{c}18.51 \\
12.68-33.45\end{array}$ & $1.85 \pm 0.22$ & 6.27 & 0.99 & 0.962 \\
\hline & $10 \mathrm{ppm}+25 \mathrm{CO}_{2}$ & $\begin{array}{c}1.82 \\
1.53-2.10\end{array}$ & $\begin{array}{c}10.37 \\
7.94-15.35\end{array}$ & $2.17 \pm 0.23$ & 2.90 & 0.40 & 0.983 \\
\hline & $\begin{array}{l}20 \mathrm{ppm}+12.5 \\
\mathrm{CO}_{2}\end{array}$ & $\begin{array}{c}1.55 \\
1.28-1.80\end{array}$ & $\begin{array}{c}8.23 \\
6.43-11.81\end{array}$ & $2.27 \pm 0.24$ & 1.34 & 0.71 & 0.966 \\
\hline & $20 \mathrm{ppm}+25 \mathrm{CO}_{2}$ & $\begin{array}{c}0.99 \\
0.77-1.18\end{array}$ & $\begin{array}{c}3.91 \\
3.20-5.32\end{array}$ & $2.77 \pm 0.35$ & 2.85 & 0.24 & 0.980 \\
\hline \multirow{4}{*}{ M. oleifera } & $\begin{array}{l}10 \mathrm{ppm}+12.5 \\
\mathrm{CO}_{2}\end{array}$ & $\begin{array}{c}2.91 \\
2.52-3.35\end{array}$ & $\begin{array}{c}18.54 \\
13.09-31.34\end{array}$ & $2.07 \pm 0.22$ & 4.12 & 0.24 & 0.977 \\
\hline & $10 \mathrm{ppm}+25 \mathrm{CO}_{2}$ & $\begin{array}{c}2.27 \\
1.97-2.58\end{array}$ & $\begin{array}{c}11.57 \\
8.92-16.81\end{array}$ & $2.32 \pm 0.23$ & 7.02 & 0.07 & 0.973 \\
\hline & $\begin{array}{l}20 \mathrm{ppm}+12.5 \\
\mathrm{CO}_{2}\end{array}$ & $\begin{array}{c}1.39 \\
1.10-1.66\end{array}$ & $\begin{array}{c}9.06 \\
6.87-13.74\end{array}$ & $2.02 \pm 0.23$ & 1.53 & 0.67 & 0.988 \\
\hline & $20 \mathrm{ppm}+25 \mathrm{CO}_{2}$ & $\begin{array}{c}1.25 \\
1.01-1.47\end{array}$ & $\begin{array}{c}5.81 \\
4.72-7.85\end{array}$ & $2.47 \pm 0.26$ & 3.55 & 0.31 & 0.978 \\
\hline \multirow{4}{*}{ S. chinensis } & $\begin{array}{l}10 \mathrm{ppm}+12.5 \\
\mathrm{CO}_{2}\end{array}$ & $\begin{array}{c}4.78 \\
4.05-5.94\end{array}$ & $\begin{array}{c}38.02 \\
22.90-86.98\end{array}$ & $1.82 \pm 0.23$ & 3.31 & 0.34 & 0.973 \\
\hline & $10 \mathrm{ppm}+25 \mathrm{CO}_{2}$ & $\begin{array}{c}3.45 \\
3.01-4.01\end{array}$ & $\begin{array}{c}21.48 \\
14.91-37.42\end{array}$ & $2.07 \pm 0.22$ & 4.87 & 0.18 & 0.972 \\
\hline & $\begin{array}{l}20 \mathrm{ppm}+12.5 \\
\mathrm{CO}_{2}\end{array}$ & $\begin{array}{c}2.22 \\
1.91-2.54\end{array}$ & $\begin{array}{c}12.52 \\
9.44-18.94\end{array}$ & $2.19 \pm 0.22$ & 1.36 & 0.71 & 0.992 \\
\hline & $20 \mathrm{ppm}+25 \mathrm{CO}_{2}$ & $\begin{array}{c}1.56 \\
0.73-2.08\end{array}$ & $\begin{array}{c}8.32 \\
7.20-34.19\end{array}$ & $2.26 \pm 0.23$ & 9.11 & 0.02 & 0.925 \\
\hline \multirow{4}{*}{ R. communis } & $\begin{array}{l}10 \mathrm{ppm}+12.5 \\
\mathrm{CO}_{2}\end{array}$ & $\begin{array}{c}9.27 \\
6.77-16.33\end{array}$ & $\begin{array}{l}136.92 \\
53.31- \\
887.74\end{array}$ & $1.40 \pm 0.23$ & 0.78 & 0.85 & 0.989 \\
\hline & $10 \mathrm{ppm}+25 \mathrm{CO}_{2}$ & $\begin{array}{c}6.20 \\
4.83-9.30\end{array}$ & $\begin{array}{l}104.45 \\
43.69- \\
563.85\end{array}$ & $1.34 \pm 0.22$ & 2.98 & 0.39 & 0.967 \\
\hline & $\begin{array}{l}20 \mathrm{ppm}+12.5 \\
\mathrm{CO}_{2}\end{array}$ & $\begin{array}{c}3.97 \\
3.35-4.88\end{array}$ & $\begin{array}{c}38.86 \\
22.61-96.12\end{array}$ & $1.66 \pm 0.22$ & 0.98 & 0.80 & 0.992 \\
\hline & $20 \mathrm{ppm}+25 \mathrm{CO}_{2}$ & $\begin{array}{c}2.66 \\
2.29-3.06\end{array}$ & $\begin{array}{c}17.21 \\
12.28-28.60\end{array}$ & $2.02 \pm 0.22$ & 1.15 & 0.76 & 0.994 \\
\hline
\end{tabular}

Table 9. Joint action effect of $10 \mathrm{ppm}$ of four plant essential oils fumigation toxicity and in combination with two modified atmospheres treatments against the adults of $C$. maculatus after exposure periods

\begin{tabular}{|c|c|c|c|c|c|c|c|c|c|c|}
\hline \multirow{3}{*}{$\begin{array}{l}\text { Essential } \\
\text { oils } \\
\text { treatments }\end{array}$} & \multicolumn{10}{|c|}{ Adults mortalities } \\
\hline & \multirow{2}{*}{$\begin{array}{c}\text { Exposure } \\
\text { period } \\
\text { (days) }\end{array}$} & \multirow{2}{*}{$\begin{array}{c}10 \\
\text { ppm } \\
\text { oil } \\
\text { alone }\end{array}$} & \multicolumn{2}{|c|}{$\mathrm{CO}_{2}$ alone } & \multicolumn{2}{|c|}{$\begin{array}{c}\text { Oil+CO } \mathrm{CO}_{2} \\
\text { Combination } \\
\end{array}$} & \multicolumn{2}{|c|}{$\begin{array}{c}\text { Co-toxicity } \\
\text { factor }\end{array}$} & \multicolumn{2}{|c|}{$\begin{array}{c}\text { Type of join } \\
\text { action }\end{array}$} \\
\hline & & & CA1 & CA2 & CA1 & CA2 & CA1 & CA2 & CA1 & $\mathrm{CA} 2$ \\
\hline \multirow{4}{*}{ P. amigdalus } & 3 & 38.8 & 18.8 & 37.7 & 53.3 & 66.6 & 19.12 & 9.49 & $\mathrm{D}$ & $\mathrm{D}$ \\
\hline & 5 & 47.7 & 25.5 & 48.8 & 73.3 & 81.1 & 12.69 & 0 & $\mathrm{D}$ & $\mathrm{D}$ \\
\hline & 7 & 63.3 & 35.5 & 65.5 & 84.4 & 95.5 & -6.19 & 0 & $\mathrm{D}$ & $\mathrm{D}$ \\
\hline & 3 & 33.3 & 18.8 & 37.7 & 52.2 & 64.4 & 34.29 & 9.15 & S & $\mathrm{D}$ \\
\hline \multirow[t]{3}{*}{ M. oleifera } & 5 & 40 & 25.5 & 48.8 & 65.5 & 78.8 & 26.29 & 2.52 & S & $\mathrm{D}$ \\
\hline & 7 & 54.4 & 35.5 & 65.5 & 82.2 & 88.8 & -3.37 & 0 & $\mathrm{D}$ & $\mathrm{D}$ \\
\hline & 3 & 18.8 & 18.8 & 37.7 & 33.3 & 48.8 & 30.67 & 3.45 & $S$ & $\mathrm{D}$ \\
\hline \multirow[t]{3}{*}{ S. chinensis } & 5 & 24.4 & 25.5 & 48.8 & 52.2 & 63.3 & 23.77 & 0.11 & S & $\mathrm{D}$ \\
\hline & 7 & 32.2 & 35.5 & 65.5 & 64.4 & 74.4 & 5.33 & 0 & $\mathrm{D}$ & $\mathrm{D}$ \\
\hline & 3 & 14.4 & 18.8 & 37.7 & 24.4 & 38.8 & 23.93 & 4.07 & $S$ & $\mathrm{D}$ \\
\hline \multirow[t]{2}{*}{ R. communis } & 5 & 18.8 & 25.5 & 48.8 & 33.3 & 44.4 & -1.84 & -8.37 & $\mathrm{D}$ & $\mathrm{D}$ \\
\hline & 7 & 27.7 & 35.5 & 65.5 & 45.5 & 55.5 & -1.54 & -16.80 & D & D \\
\hline
\end{tabular}

$\mathrm{CA} 1: 12.5 \% ; \mathrm{CO}_{2}$ and, $\mathrm{CA} 2: 25 \% \mathrm{CO}_{2}$ 
Table 10. Joint action effect of $20 \mathrm{ppm}$ of four plant essential oils fumigation toxicity and in combination with two modified atmospheres treatments against the adults of $C$. maculatus after exposure periods

\begin{tabular}{|c|c|c|c|c|c|c|c|c|c|c|}
\hline \multirow{3}{*}{$\begin{array}{l}\text { Essential } \\
\text { oils } \\
\text { treatments }\end{array}$} & \multicolumn{10}{|c|}{ Adults mortalities } \\
\hline & \multirow{2}{*}{$\begin{array}{c}\text { Exposure } \\
\text { period } \\
\text { (days) }\end{array}$} & \multirow{2}{*}{$\begin{array}{c}10 \\
\text { ppm } \\
\text { oil } \\
\text { alone }\end{array}$} & \multicolumn{2}{|c|}{$\mathrm{CO}_{2}$ alone } & \multicolumn{2}{|c|}{$\begin{array}{c}\text { Oil+CO } \mathrm{CO}_{2} \\
\text { Combination }\end{array}$} & \multicolumn{2}{|c|}{$\begin{array}{l}\text { Co-toxicity } \\
\text { factor }\end{array}$} & \multicolumn{2}{|c|}{$\begin{array}{l}\text { Type of join } \\
\text { action }\end{array}$} \\
\hline & & & CA1 & CA2 & CA1 & CA2 & CA1 & CA2 & CA1 & CA2 \\
\hline \multirow{3}{*}{$\begin{array}{c}P . \\
\text { amigdalus }\end{array}$} & 3 & 45.5 & 18.8 & 37.7 & 76.6 & 91.1 & 7.46 & -12.90 & $\mathrm{D}$ & $\mathrm{D}$ \\
\hline & 5 & 53.3 & 25.5 & 48.8 & 88.8 & 100 & 0.13 & -15.90 & $\mathrm{D}$ & $\mathrm{D}$ \\
\hline & 7 & 71.1 & 35.5 & 65.5 & 100 & 100 & -14.5 & -4.50 & $\mathrm{D}$ & $\mathrm{D}$ \\
\hline \multirow{3}{*}{ M. oleifera } & 3 & 36.6 & 18.8 & 37.7 & 74.4 & 81.1 & 0.19 & -8.78 & $\mathrm{D}$ & $\mathrm{D}$ \\
\hline & 5 & 42.2 & 25.5 & 48.8 & 85.5 & 93.3 & 0 & 11.26 & $\mathrm{D}$ & $\mathrm{D}$ \\
\hline & 7 & 62.2 & 35.5 & 65.5 & 94.4 & 100 & -8.56 & -11.20 & D & $\mathrm{D}$ \\
\hline \multirow{3}{*}{ S. chinensis } & 3 & 28.8 & 18.8 & 37.7 & 62.2 & 68.8 & -11.40 & -13.60 & $\mathrm{D}$ & $\mathrm{D}$ \\
\hline & 5 & 35.5 & 25.5 & 48.8 & 75.5 & 84.4 & 4.60 & 13.50 & $\mathrm{D}$ & $\mathrm{D}$ \\
\hline & 7 & 48.8 & 35.5 & 65.5 & 88.8 & 100 & -4.87 & -23.80 & $\mathrm{D}$ & A \\
\hline \multirow{3}{*}{ R. communis } & 3 & 18.8 & 18.8 & 37.7 & 46.6 & 58.8 & -26.5 & -25.5 & A & A \\
\hline & 5 & 28.8 & 25.5 & 48.8 & 53.3 & 71.1 & -24.8 & -34.30 & A & A \\
\hline & 7 & 33.3 & 35.5 & 65.5 & 67.7 & 82.2 & -28.00 & -40.40 & A & A \\
\hline
\end{tabular}

$\mathrm{CA} 1: 12.5 \% ; \mathrm{CO}_{2}$ and, $\mathrm{CA} 2: 25 \% \mathrm{CO}_{2}$

\section{Discussion}

Our work has shown that there was a significant difference in repellence of essential oils against $C$. maculatus adults. $P$. amigdalus oil repellence decreased in 7 days more than the other three oil. We also found that $C$. maculatus adult fumigant toxicity was seen in all four essential oils. The mortality of adults with various oils treated with $C$. maculatus differed significantly. There was also a direct correlation between fumigant toxicity and repellent. For instance, $P$. amigdalus oil had the highest repellence effects against the adults of $C$. maculatus and its toxicity to fumigant was significantly higher amongst the four essential oils studied. Elgizawy, et al., (2019) detect the chemical composition of the essential oil derived from the fruits of Litsea cubeba (Lauraceae).In addition, to evaluate the contact and fumigant toxicity and repellent activities of the essential oil and twomain active ingredients against the adults of two stored grain insect pests; rice weevil, Sitophilus oryzae (L.) and the red flour beetle, Tribolium castaneum (Herbst.) in the laboratory, the results showed that the essential oil, citral and Dlimonene had higher fumigation toxicity on the same insects4.44, 4.89 and $16.68 \mu \mathrm{g} / \mathrm{l}$, respectively. Guenther, (1948) confirmed that, while a number of chemically unrelated compounds were found in the essential oils, four main groups were possible: terpenes, straight-chain compounds, benzene derivatives, and miscellaneous. Ryan and Byrne, (1988) reported that, different experiments showed that inhibition of acety lcholinesterase may be the mode of action of the fum igant toxicity of essential oil against insects. Tembo and Murfitt, (1995) suggested that the mortality was due to anoxia. This is confirmed by our findings that when plant oils are used in combination with controlled atmosphere treatment fumigant toxicity was significantly enhanced. It is well known that the controlled atmosphere contributes to insect control two physiological and biological characteristics of stress. Donahaye and Navarro,(2000). One is the reduction in $\mathrm{O}_{2}$ concentration, resulting in hypoxia or anoxia; another is the increase in $\mathrm{CO}_{2}$ concentration, producing hypercarbia, or a combination of both.

Our study also showed that, there were significantly different interactions between plant oil and controlled atmosphere treatment. This indicated that essential oils could exhibit maximum fumigant toxicity only in certain plant oils. Recent research by Wang et al., (2001) showed that the development and reproduction of L. bostrychophila in such a regulated environment were successful, resulting mainly in mortality from plant oil. In combination with controlled atmosphere procedures, the increased toxicity of oils may be a result of controlled atmospheric therapies that enhancing the up-take of the plant essential oils by the insects.

For centuries, plants such as pyrethrum (Tanacetum cinerariifolium (Trevir.) Schultz-Bip.), tobacco (Nicotiana tobacum L.), and neem (Azadirachta spp.) have been known to have components with insecticidal activity and used for control of agricultural pests in China Tsai,(1982) suggested that oils could be considered as efficient repellents and fumigants and also could be integrated into other pest management schemes for control of $C$. maculatus in sealed storage situations.

\section{Conclusion}

The findings of this study indicate that there were significant differences in the repellence activity of four essential oils against the adult of $C$. maculatus. Within 7 days, the $P$. amigdalus oil repellence decreased more than that of the other three oils. As well all four essential oils demonstrated some 
fumigant toxicity against adults of $C$. maculatus. Mortality of adults of $C$. maculatus treated with different oils varied significantly. The use of $\mathrm{CO}_{2}$ concentration appears to have an additive effect when combined with four essential oils against the adult of C. maculatus as evidenced by significant decrements in $\mathrm{LT}_{50}$ and $\mathrm{LT}_{95}$ values for the adults and the mortality percentage were enhanced. These results indicate that combination of four essential oil with $\mathrm{CO}_{2}$ can be potential as an alternative application to the most commonly used commercial fumigants, methyl bromide and phosphine.

\section{References}

Abbott, W. S. (1925): A method of computing the effectiveness of insecticide. J. Econ. Ent. 18 (2), 265-267.

Darwish A.A.; El-Lakwah F. A. and Khalid O. Nour-Eldin H. (1993): Efficiency of controlled atmospheres containing various $\mathrm{CO}_{2}$ conc. and $\mathrm{N}_{2}$ against T. granarium. Annals of Agric. Sci., Moshtohor, 619-641.

Donahaye, E. and Navarro, S. (2000): Comparisons of energy reserves among strains of Tribolium castaneum selected for resistance to hypoxia and hypercarbia, and the unselected strain. J. Stored Prod. Res. 36:223-234.

Elgizawy, K. KH.; El-Shewy, A.M. and Amany R. Morsy (2019): Evaluation of Essential Oil and its Main Active Ingredients of Chinese Litsea cubeba Against Two Stored-Grain Insects. Academic Journal of Entomology 12 (2): 29-39.

El-lakwah. F.A.; Abd El Aziz, A. E. and ElKashlan, I.H. (2000): joint action and effectiveness of black pepper seeds extract with modified atmospheres against some stored product insects. Annals of Agric., Sc., Moshtoher, 38(4):2529-2542.

Finney, D. J. (1971): "Probit Analysis". Cambridge University Press, Cambridge, London, 333pp.

Gbaye, O.; Millard, J. and Holloway, G. (2012): Synergistic effects of geographical strain, temperature and larval food on insecticide tolerance in Callosobruchus maculatus (F.). Journal of Applied Entomology; 136 (4):282-91.

Guenther, E. (1948): The essential oils, vol. 1. Van Nostrand, New York.

Ileke, K. D.; Bulus, D. S. and Aladegoroye, A. Y. (2017):Effects of three medicinal plant products on survival, oviposition and progeny development of cowpea bruchid, Callosobruchus maculatus (Fab.)[Coleoptera: Chrysomelidae] infesting cowpea seeds in storage. Jordan Journal of Biological Science. 6(1):61-6.

Isman, M. B. (2006): Botanical insecticides, deterrents, repellents in modern agriculture and an increasingly regulated world. Annual Review of Entomology, 51: 45-66.
Kang, J. K.; Pittendrigh, B. R. and Onstad, D. W. (2013):Insect resistance management for stored product pests: a case study of cowpea weevil (Coleoptera: Bruchidae). Journal of Economic Entomology; 106(6):2473-90.

Lee, B. H.; Annis, P. C.; Tumaalii, F. and Choi, W. S. (2004): Fumigant toxicity of essential oils from the Myrtceae family and 1,8-Cineole against 3 major stored-grain insects. Journal of Stored Product Research, 40: 553-564.

Lee, B. H.; Choi, W. S.; Lee, S. E. and Park, B. S. (2001): Fumigant toxicity of essential oils and their constituent compounds towards the rice weevil, Sitophilus oryzae. Journal of Crop Protection Research, 20: 317-320.

Mansour, N.A.; El-Defrawwi, M. E.; Toppozada, A and Zeid, M. (1966): Toxicological studies on the Egyptian cotton leaf worm, Prodenia litura potentiation and antagonism of organophosphorus and carbamate insecticides. J. Econ. Entomol., 59, 307-311.

Massango, H.; Faroni, L.; Haddi, K.; Heleno, F.; Jumbo, L. V. and Oliveira, E. (2017): Toxicity and metabolic mechanisms underlying the insecticidal activity of parsley essential oil on bean weevil, Callosobruchus maculatus. Journal of Pest Science. 90(2):723-33.

Matthews, G. A. (1993): Insecticide Application in Stores, 305-315. In: Application Technology for Crop Protection (Eds. G. A. Matthews \& E. C. Hislop), CAB, London, 368 pp.

Mbata, G. N.; Philips, T. W. and Payton, M. E. (2009): Effects of cowpea varietal susceptibility and low pressure on the mortality of life stages of Callosobruchus maculatus (Coleoptera: Bruchidae). Journal of Stored-Product Research, 45: 232-235.

Meaklim, J. (1998): Phosphine toxicity: are phosphine users, or the general community, at risk of adverse health effects. In: Banks, H.J., Wright, E.J., Damcevski, K.A. (Eds.), Stored Grain in Australia. Proceedings of the Australia Postharvest Technical Conference, Canberra, 2629 May 1998, 119-125.

Mueller, D. K. (1990): Fumigation. In: Mallis, A. (Ed.), Handbook of pest control. Franzak and Foster Co. Cleveland, Ohio, 901-939.

Navarro, S. (2006): Modified atmospheres for the control of stored product insects and mites. In: Heaps, J.W. (Ed), Insect management for food storage and processing. AACC International, St. Paul, Minnesota, USA, 105-145.

Noack, S. and Reichmuth, CH. (1978): Einrechnerisches Verfahren Zur Bestimmung Von beliebigen Dosis-Werten eines Wirkstoffes aus empirisch Dosis-wirkungs-Daten Mitt. Boil Bundesanstalt fur Land Forstwirtsch, Berlin Dahlem, Haft 185; 1-49.

Rajendran, S. and Sriranjini, V. (2008): Plant products as fumigants for stored-product insect 
control. Journal of Stored Products Research, 44: 126-135.

Ryan, M. F. and Byrne, O. (1988):Plant-insect coevolution and inhibition of acetylcholinesterase. J. Chem. Ecol. 14: 1,965-1,975.

Singh, B. B.; Ajeigbe, H. A.; Tarawali, S. A.; Fernandez-Rivera, S. and Abubakar, $M$. (2003): Improving the production and utilization of cowpea as food and fodder, Field Crops Research, 84(2):169-177.

Steel, R.G.D.; Torrie, J.H. and Dickey, D. (1997): Principles and Procedure of Statistics. A Biometrical Approach 3rd Ed. McGraw Hill BookCo. Inc., New York. pp. 352-358.
Su, H. C.F. (1989): Laboratory evaluation of dill seed extract in reducing infestation of rice weevil in stored wheat. J. ENT. Sci. 24:317-320.

Tembo, E. and Murfitt, R.F.A. (1995): Effects of combining vegetable oil with pirimiphos-methyl for protection of stored wheat against Sitophilus granarius (L.). J. Stored Prod. Res. 31:77-81.

Tsai, J. H. (1982): Entomology in PeopleÕs Republic of China. J. N.Y. Entomol. Soc. 89:186 -212.

Wang, J. J.; Tsai, J. H.; Zhao, Z. M. and Li, L. S. (2001): Interactive effects of temperature and controlled atmosphere at biologically relevant levels on development and reproduction of the psocid, Liposcelis bostrychophila Badonnel (Psocoptera: Liposcelididae). Int. J. Pest Manag. 47:55- 62. 
التأثير السام لأريعة زيوت نباتية عطرية بمفردها وعند خلطها مع جو معدل متحكم به ضد خنفساء اللوبيا تحت ظروف المعل

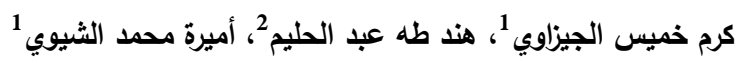

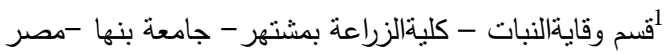

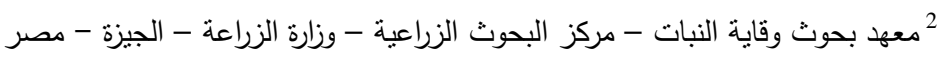

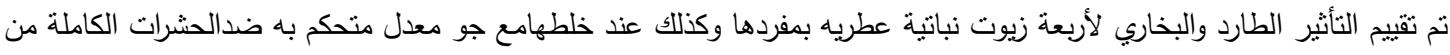

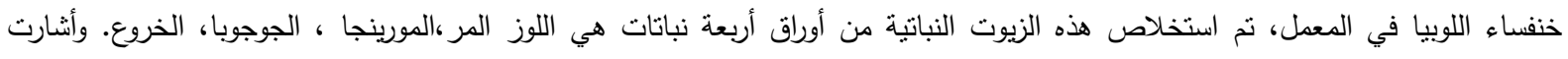

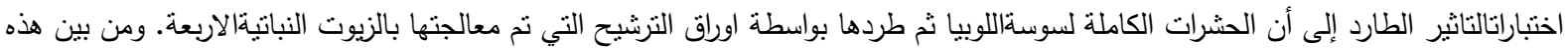

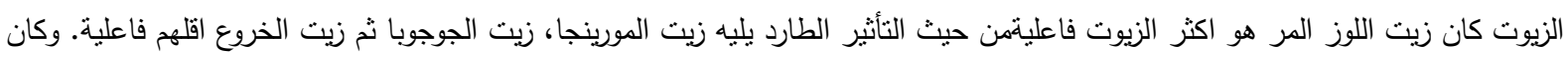

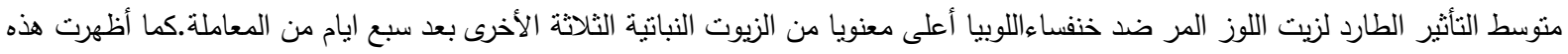

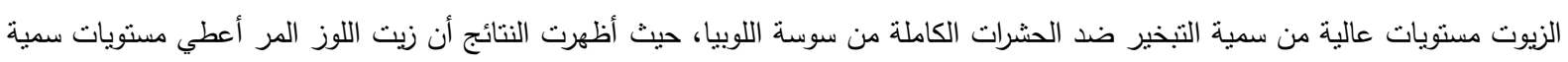

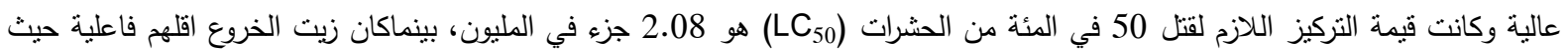
اعطي قيم منخفضة من (LC

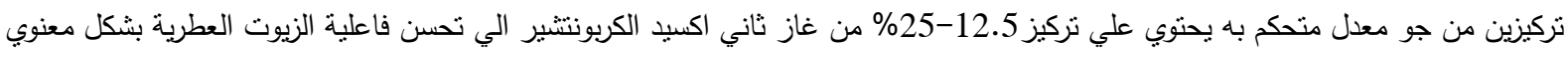

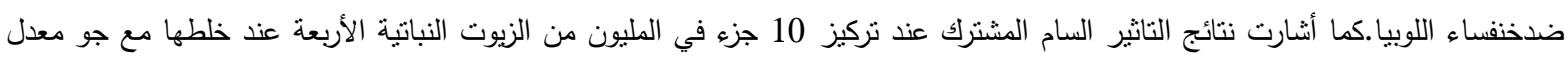

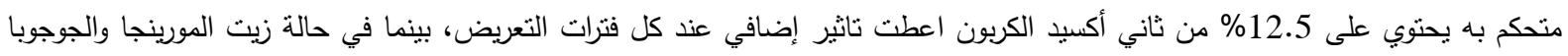

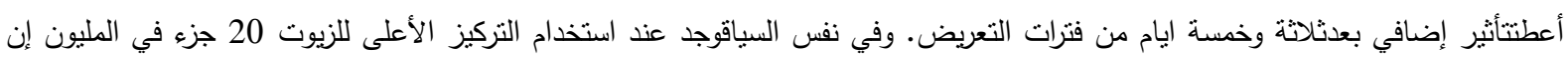

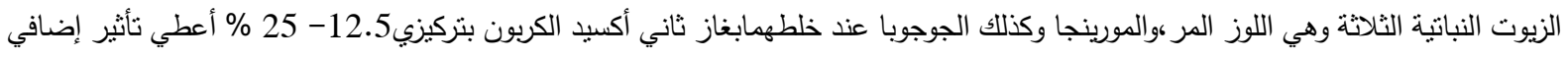

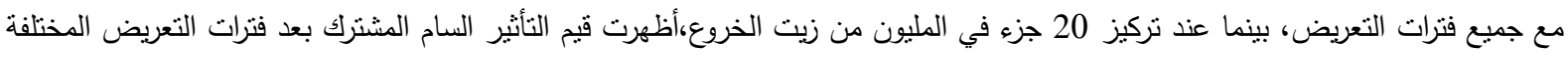

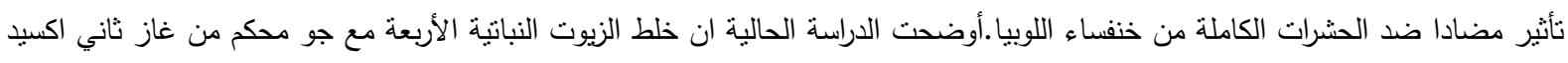
الكربون يقوم بتحسين سمية الزيوت النباتية بشكل افضل من استخدامها بصورة منفردة عند مكافحةشثرة خنفساء اللوبياعلى الحبوب المخزونة. 